\title{
INTERNATIONAL TRADE IN PANDEMIC: STUDY ON THE CHALLENGES AND OPPORTUNITIES OF SMOOTH TRADE
}

\author{
Mohit Goyal \\ Symbiosis Center for Management Studies, Pune \\ DOI: 10.46609/IJSSER.2021.v06i07.023 URL: https://doi.org/10.46609/IJSSER.2021.v06i07.023
}

\begin{abstract}
The research paper aims to find out impact of COVID-19 pandemic on international trade. The disease burdenis studied on countries classified under two categories i.e., major importing and exporting countries. Moreover, the research talks about some challenges in maintaining the flow of international trade during COVID. Lastly, the paper also presents some short term and longterm solutions for ensuring smooth flow of trade between countries, suggesting a path for global economic recovery after the pandemic.
\end{abstract}

Keywords: International, Trade, COVID-19. Import, Export, Transparency, Burden, Global, Supply chain, Recovery, Vaccination.

\section{Introduction}

The recent outbreak of COVID-19 has caused enormous social and economical change. Also simply known as the coronavirus, it was previously referred by its provisional name 2019 novel coronavirus (2019-nCoV). It was first identified in Wuhan, China. The World Health Organization declared COVID-19 as a Public Health Emergency of International Concern on $30^{\text {th }}$ January 2020 and a Pandemic on $11^{\text {th }}$ March 2020.

This disease was initially thought as a cause of worry onlyin China and African countries but quickly spread all over the world (around 216 countries) because of various reasons like lack of information and knowledge, incomplete evidences, etc. As a result, governments of several countries were forced to put various restrictions on the citizens to contain the spread of virus. Despite of numerous restrictions, the number of covid cases increased sharply during the first and second wave, however the number is expected to stabilise in the near future because of the ongoing vaccination programme across the world. Apart from the increasing number of infections there are other aspects of these restrictions which need to be looked upon. 
COVID-19 is a public health emergency which will be followed by economic and political instability.

The Pandemic has affected all sectors of the economy. International Trade is especially hit hard. According to the WTO, the world merchandise trade is forecast to fall $9.2 \%$ in 2020 (Falling $14.3 \%$ compared to the previous quarter). This projected decline is less than the $12.9 \%$ drop foreseen in the optimistic scenario from the April trade forecast. However, trade in COVID related products was growing strongly in 2020 showing the ability of international trade to help the governments to obtain needed supplies.

\section{Current situation of international trade}

The measures taken by various governments to control the rate of infection of COVID-19 has resulted in serious consequences for major economies of the world. Activities of major producing units have been disrupted, starting from Asia, Europe, North America and then the rest of the world because of various restrictions like widespread border closures. As a result, there has been an exponential rise in the rate of unemployment, continuous reduction in aggregate demand and aggregate supply of non-essential goods and services. According to the world bank, against this backdrop the GDP of 2020 registered the sharpest contraction since second world war (World Bank 2020).

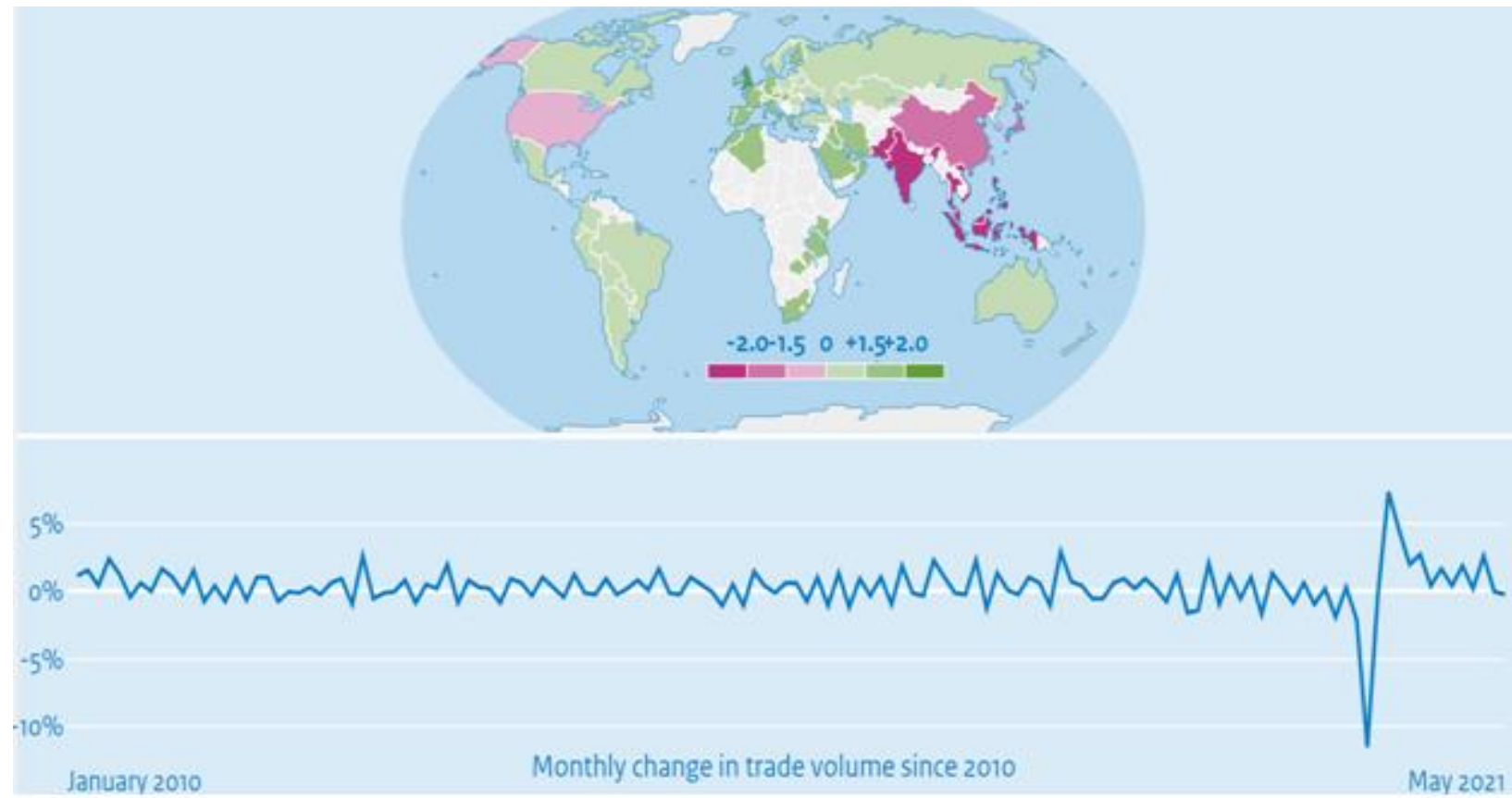

Figure 1Monthly change in trade volume Source: $\underline{\text { https://www.cpb.nl/en/worldtrademonitor }}$ 
The volume of global trade in goods fell by $16.9 \%$ in May 2020 as compared to May 2019 . World Trade momentum was 3.1\% in May 2021 (non-annualised; 3.1\% in April unchanged from initial estimate). World Industrial production momentum was $0.3 \%$ in May 2021 (nonannualised, $1.6 \%$ in April; initial estimate 1.8\%).

World Industrial production decreased 1.1\% (in May 2021) month on month (having increased $0 \%$ in April 2021, initial estimate $0.2 \%$ ), which was mostly driven by Japan (-6.5\%), China ($1.6 \%)$, and other emerging economies $(-4.0 \%)$

\subsection{COVID-19 Burden in Exporting Countries}

Various COVID restrictions has reduced people's mobility in workplaces which reduces the supply of goods and lower the price elasticity, shifting the country's supply curve upward and making it steeper. In simple words, it reduces the scale of production and decreases the export supply.

Two important elements in determining the effect of COVID-19 on exports are:

\section{Decreased domestic demand for exported products}

Higher burden of COVID-19 may not only shrink the scale of production but may also reduce the domestic demand for that product. If the decrease in domestic demand is sufficiently larger than the decrease in production, a net increase in exports can be achieved by diverting the excess production to the export market.

\section{Introducing remote work/operation on productivity}

Almost every business, be it MSME or MNC, has tried to adopt or successfully adoptedwork from home style of working which can improve productivity and thus lead to an increase in exports. On the other hand the scale of production would decrease in industries where remote work/operation is less feasible. E.g., Labour intensive industries. It is also not feasible in countries with less developed information technology (IT) infrastructure; hence the productivity will decrease which will lead to decreased exports. 
International Journal of Social Science and Economic Research

ISSN: 2455-8834

Volume:06, Issue:07 "July 2021"

Major exporting countries in world (before COVID):

Table 1

\begin{tabular}{|c|c|c|c|c|}
\hline Rank & Country & $\begin{array}{c}\text { Exports } \\
\text { (millions of \$) }\end{array}$ & $\%$ of GDP & Year \\
\hline & World & $24,933,017.78$ & $30.5 \%$ & 2019 \\
\hline 1 & "China & $2,643,376.93$ & $18.5 \%$ & 2019 \\
\hline 2 & 登 United States & $2,528,267.00$ & $11.7 \%$ & 2019 \\
\hline 3 & Germany & $1,811,351.01$ & $46.9 \%$ & 2019 \\
\hline 4 & - Japan & $904,882.65$ & $18.5 \%$ & 2019 \\
\hline 5 & France & $891,181.57$ & $31.8 \%$ & 2019 \\
\hline 6 & United Kingdom & $879,917.16$ & $31.6 \%$ & 2019 \\
\hline 7 & Netherlands & $755,770.91$ & $83.3 \%$ & 2019 \\
\hline 8 & :o: South Korea & $669,593.70$ & $39.9 \%$ & 2019 \\
\hline - & * Hong Kong & $649,022.69$ & $177.5 \%$ & 2019 \\
\hline 9 & Singapore & $645,612.45$ & $173.5 \%$ & 2019 \\
\hline 10 & Italy & $632,107.22$ & $31.5 \%$ & 2019 \\
\hline
\end{tabular}

Source: Wikipedia (World Bank) 


\section{International Journal of Social Science and Economic Research}

ISSN: $2455-8834$

Volume:06, Issue:07 "July 2021"

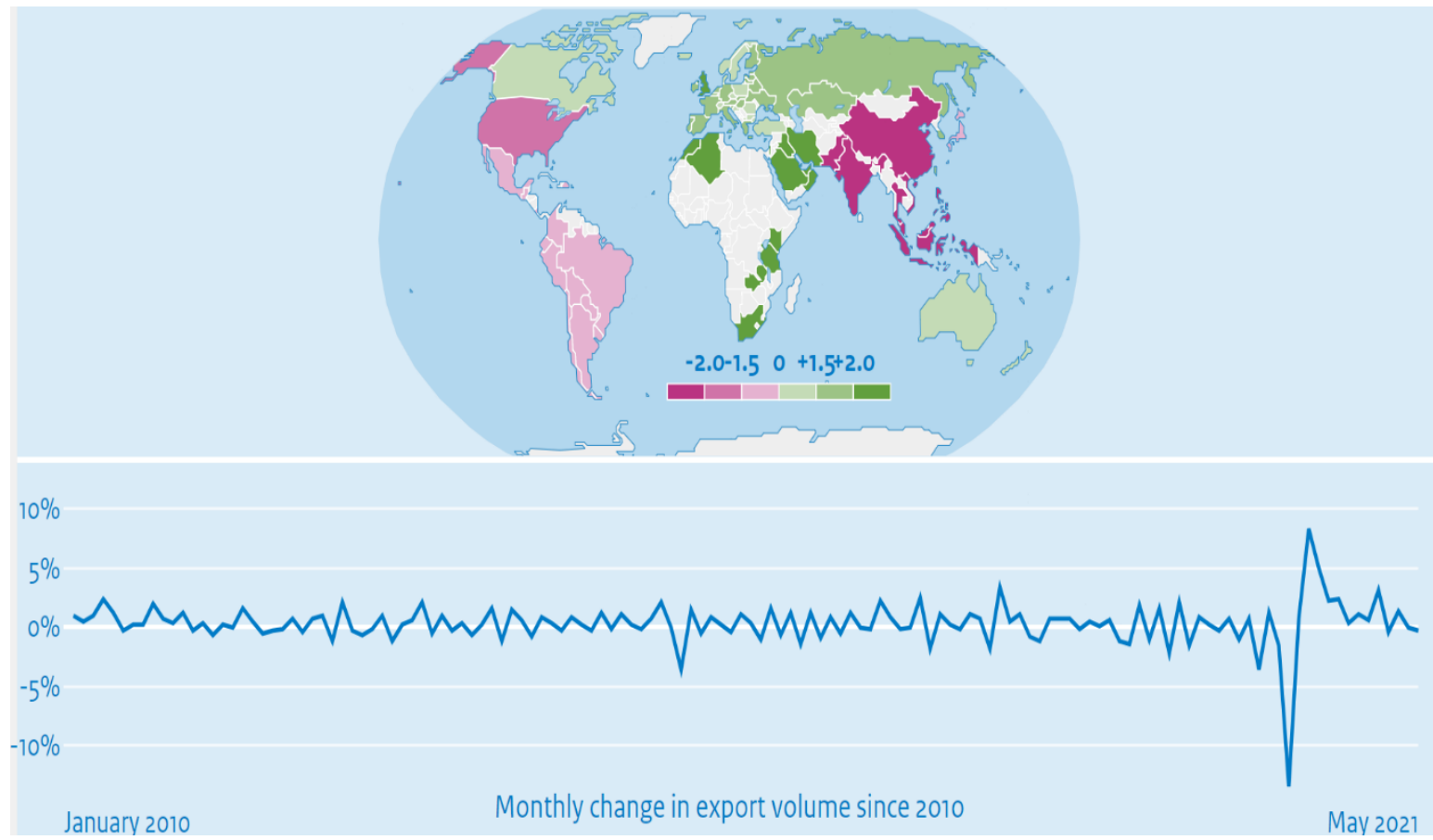

Figure 2 Monthly change in export volume

Source: https://www.cpb.nl/en/worldtrademonitor

Table 2 Change in global trade in goods

\begin{tabular}{lcc}
\hline & Exports & Imports \\
\hline World & -18.3 & -15.8 \\
\hline Advanced economies & -22.7 & -15.8 \\
\hline United States & -30.8 & -15.8 \\
\hline Japan & -22.1 & -4.4 \\
\hline Eurozone & -22.0 & -16.6 \\
\hline Emerging economies & -12.8 & -15.8 \\
\hline China & -7.7 & -13.8 \\
\hline Emerging Asian countries (excluding China) & -13.1 & -17.2 \\
\hline Eastern Europe and Commonwealth of Independent States (CIS) & -4.4 & -13.4 \\
\hline Latin America and the Caribbean & -26.1 & -27.4 \\
\hline Africa and the Middle East & -13.9 & -2.5
\end{tabular}

Source: Economic commission for Latin America and Caribbean (ECLAC), on the basis of Netherlands Bureau of economic policy analysis $(C P B)$ 
International Journal of Social Science and Economic Research

ISSN: 2455-8834

Volume:06, Issue:07 "July 2021"

The drop in the first five months of 2020 particularly affected the exports from the United States, Japan and the European Union. The economic contraction in China was much smaller than the global average as the country controlled the outbreak and reopened its economy relatively quickly.

The contribution of exports in the GDP of UK was 31.6\% in 2019 (table 1). According to the government of UK, during April to June 2020 majority of the exporting businesses (72\%) are exporting less than normal, 18\% whose exports are not affected by COVID-19, 3\% reported that they are exporting more than normal and $2 \%$ of the businesses have reported that they have stopped exporting.

\subsection{Burden of COVID in Importing Countries}

Decrease in the aggregate demand in the country will mainly affect the trade situation in an importing country. Various restrictions and nationwide lockdowns reduce people's earning and thus lead to a drop in aggregate demand. However even if people maintain their earnings, the fear of getting the infection reduces the mobility of individuals voluntarily which results in decrease in aggregate demand.

Various studies and economists who studies the effect of the global recession 2008-09 suggest that negative demand shocks reduce spending on durable goods more than the spending on nondurable goods because durable goods are postpone-able. However import demand for sanitation products (Durable products) like face mask and hand sanitizers may increase due to increased domestic demand for products that protect against COVID-19.

List of major importing countries (Before COVID):

Table 3

\begin{tabular}{llll}
$\mathbf{N O}$ & COUNTRY & YEARLY IMPORTS VALUE & DATE OF INFORMATION \\
\hline $\mathbf{1}$ & UNITED STATES & $\$ 2.35$ trillion & 2017 \\
\hline $\mathbf{2}$ & CHINA & $\$ 1.89$ trillion & 2017 \\
\hline $\mathbf{3}$ & GERMANY & $\$ 1.10$ trillion & 2017 \\
\hline $\mathbf{4}$ & JAPAN & $\$ 625$ billion & 2017 \\
\hline $\mathbf{5}$ & FRANCE & $\$ 624$ billion & 2017 \\
\hline $\mathbf{6}$ & UNITED KINGDOM & $\$ 602$ billion & 2017 \\
\hline $\mathbf{7}$ & SOUTH KOREA & $\$ 457$ billion & 2017 \\
\hline $\mathbf{8}$ & CANADA & $\$ 443$ billion & 2017 \\
\hline $\mathbf{9}$ & NETHERLANDS & $\$ 435$ billion & 2017 \\
\hline $\mathbf{1 0}$ & INDIA & $\$ 426$ billion & 2017
\end{tabular}

Source: https://uk.worldoptions.com/news/worlds-top-exporters-and-importers 


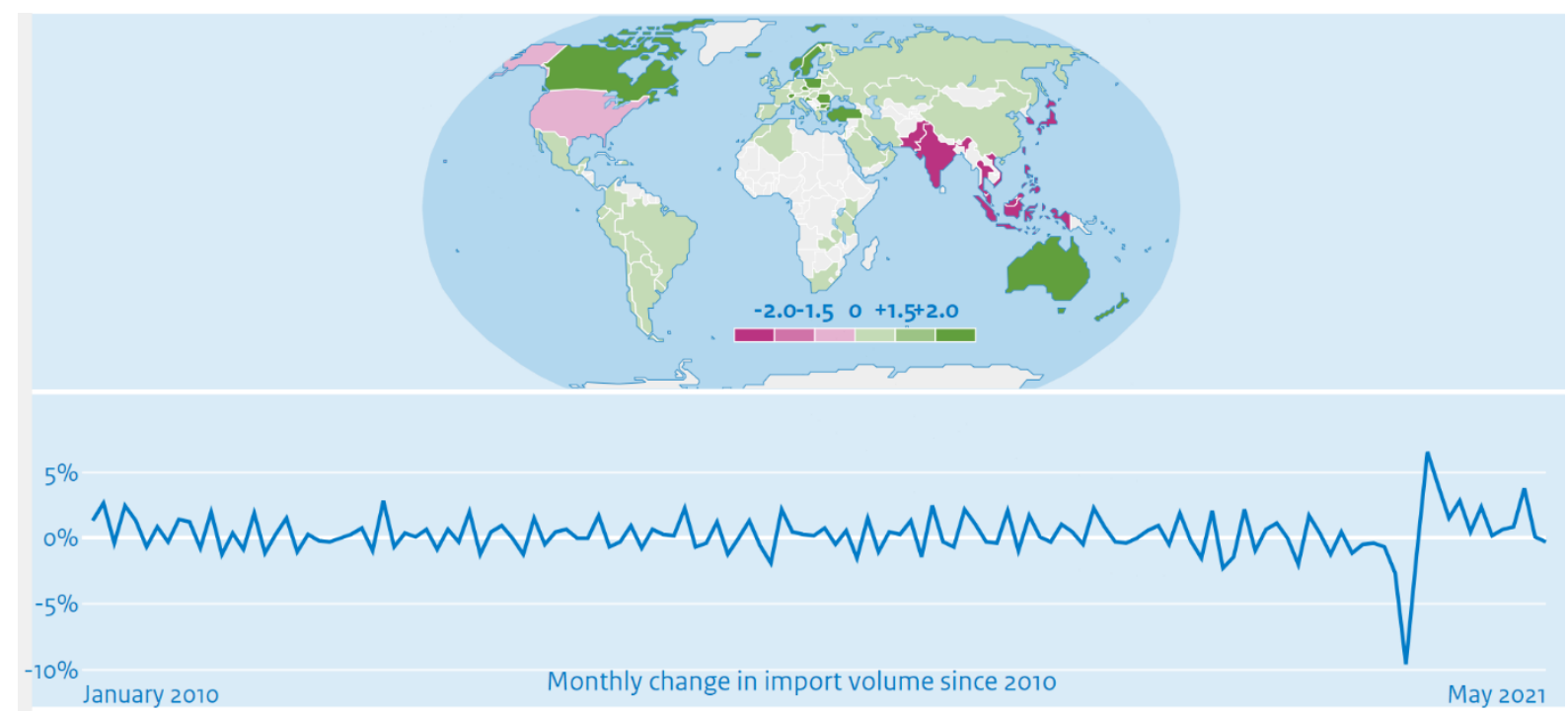

Figure 3

\section{Source: https://www.cpb.nl/en/worldtrademonitor}

Imports were roughly stable in China, United States, and United Kingdom in May 2021 as compared to May 2020 because of the efforts of the governments to slowly open up the economy.

The fall in imports of major importing countries like China, United States, Japan (table 2) was particularly in the first five months of 2020 due to a decrease in the aggregate domestic demand for exported products.

\section{Solutions to maintain International Trade in COVID-19}

A major challenge in terms of international trade is the uncertainty of COVID-19 in terms of scale and pace of infection, for how long will the restrictions be imposed, the risk about a 'third wave' hitting the world, pace of vaccinations around the world. What is clear as of now is that the virus and its after effect is not going away from the world anytime soon.

Against all uncertainty, there is a clear need to maintain the flow of trade. Trade is essential to maintain both lives and livelihoods.

The following are some actions that can be taken despite all uncertainty:

\section{Ensuring transparency to boost confidence in trade and global supply chains:}


In the time of crisis, transparent and efficient information sharing is critical to reduce duplication of efforts and increase efficient collaboration. Transparency is preciously about allowing access to information. It enables governments and traders to be updated is a rapidly evolving trade system and provides the much-needed clarity. There are various ways to ensure transparency. One such measure provided by the WTO is the Trade Policy Review Mechanism where the members of the WTO are called upon and country specific trade policy reviews and regular monitoring and reporting on the implementation of trade and trade related measures is done.

\section{Keeping global supply chains going, especially for essentials:}

One of the topmost priorities of any government or organisation is to keep the global supply chains functioning especially for essential products like medical equipment, face masks, sanitizers, food products, etc. However, there are a number of challenges in maintaining the supply chains like cancellation of passenger flights but various restrictions because of which the availability of air cargo has been limited (Graph 3). As a result, it has increased the demand for urgent supply for air cargo which has increased the prices of air cargo.Also, over 50 countries have revised the procedures at ports and border checks likeenforcing quarantine measures, additional documentation required etc.

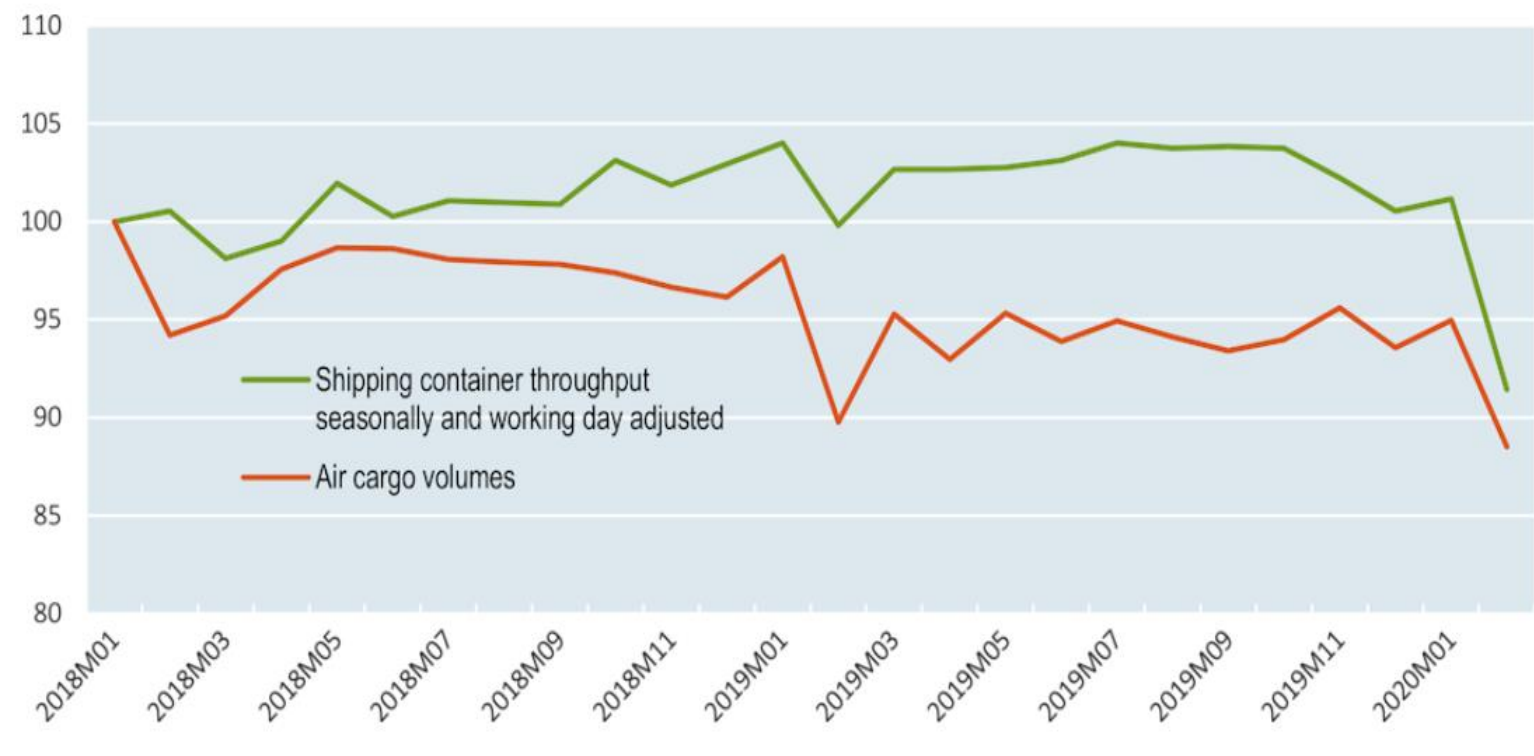

Figure 3 Sea and air cargo dropping sharply

Source: OECD, drawing on data from Innovative solutions from maritime logistics (http://www.isl.org/en/containerindex) and International Air Transport Association (http://www.iata.org/)

Following are some short-term measures that can be done in order to keep trade flowing: 


\section{International Journal of Social Science and Economic Research}

ISSN: $2455-8834$

Volume:06, Issue:07 "July 2021"

- Minimising the need for unnecessary documentation along with the interaction of customs and border officials to the maximum possible extent.

- Relying more on information and technology (IT) to help people be connected with market, avoiding delays by e-payments, e-signatures, e-contracts, etc.

- Co-operating with medical researchers about COVID-19 by ensuring smooth flow of data. Government could enable processing and cross border transfer of sensitive data to promote epidemics.

\section{Carefully examining the long-term impact of a policy formed to manage pandemic}

Policies formed today also have a long-term impact. While governments today are necessarily focussed on ensuring better health services and economic security. So, proper planning is required to ensure a robust economic recovery in long term.

\section{Conclusion}

The pandemic presents challenges unprecedented in the history of multilateral trading system. This pandemic calls for great level of international co-operation. Countries must work together; this will result in a much faster recovery than if each country acts alone. Things are slowly coming back to normal as the major economies of the world are opening up. However, policies focussing on greater good of society shall be stressed upon on various issues like vaccination, trade, health infrastructure, global supply chain, etc. With the help of international organisations like WHO, policies should be made to ensure smooth flow of vaccinations to economically poor countries from economically strong countries as vaccination is the only way ahead to bring an end to the pandemic.

\section{References}

- https://unctad.org/system/files/official-document/osg2020d1_en.pdf

- https://www.oecd.org/coronavirus/policy-responses/covid-19-and-international-tradeissues-and-actions-494da2fa/

- https://www.worldometers.info/coronavirus/\#countries

- $\quad$ https://en.wikipedia.org/wiki/Economic_impact_of_the_COVID-19_pandemic

- $\quad$ https://www.jstor.org/stable/resrep30854.4?seq=2\#metadata info tab contents

- $\quad$ https://www.emerald.com/insight/content/doi/10.1108/AAAJ-06-2020-4634/full/html 
International Journal of Social Science and Economic Research

ISSN: 2455-8834

Volume:06, Issue:07 "July 2021"

- https://www.cambridge.org/core/journals/european-journal-of-riskregulation/article/covid19-pandemicand-international-trade-temporary-turbulence-orparadigm-shift/8C76595B1E954E601EAF91F0E6C23492

- https://www.wto.org/english/res_e/booksp_e/strengthening_africas_ch_conclusion_e.pdf

- https://repositorio.cepal.org/bitstream/handle/11362/45878/1/S2000496_en.pdf

- https://www.cpb.n1/en/worldtrademonitor

- https://www.jstor.org/stable/resrep30854.9?seq=1\#metadata_info_tab_contents

- https://www.emerald.com/insight/content/doi/10.1108/AAAJ-06-2020-4634/full/html

- https://www.thelancet.com/journals/lanplh/article/PIIS2542-5196(20)302916/fulltext\#seccestitle20

- https://www.wto.org/english/news e/pres20 e/pr862 e.htm

- https://www.cepal.org/en/publications/45878-effects-coronavirus-disease-covid-19pandemic-international-trade-and-logistics

- https://www.wto.org/english/tratop e/covid19 e/transparency report e.pdf 